\title{
10 Conclusions
}

\subsection{Summary}

The aim of this thesis was to explain different regime outcomes and the variance in the degree of democracy in post-Soviet space by studying the influence of the two main external actors, the EU and Russia. This thesis contributes to the increasing body of literature that studies the causes of democratic recession and authoritarian backlash in post-Soviet states and the role of external actors in these processes. The main focus of the study was on two most important regional actors the EU and Russia - and on their interaction in the post-Soviet area.

The thesis starts with the evaluation of regime dynamics in four post-Soviet states with very different records of democratic performance over the past fifteen years: empirical analysis shows that Georgia and Ukraine have been democratic frontrunners in post-Soviet space, whereas Armenia and Belarus are cases of authoritarian stability or even an authoritarian backlash. The empirical analysis illustrates that the four countries fall into two distinct regime groups: Armenia and Belarus as stable authoritarian regimes with a stable, lower quality of democracy, and Georgia and Ukraine as hybrid regimes - not fully democratic but much closer to the European understanding of liberal democracy.

Then the thesis explores the extent to which the external actors contribute to the qualitative differences in regime outcomes and in quality of democracy between the two groups. In so doing, the study does not intend to measure the relative casual power of the external variables vis-à-vis the domestic explanatory variables. Instead, it looks at how external conditions empower or impede the domestic conditions that are important for regime dynamics. Thus, the study looks at the interplay between domestic and external conditions, its impact on regime dynamics and the variance in quality of democracy. Therefore, first, the thesis starts with identifying the domestic conditions that have the biggest impact on regime dynamics and quality of democracy. Second, I look at how the two regional actors Russia and the EU - adapt their strategies to the varying domestic conditions to achieve their goals in the region. To do that, this thesis develops separate analytical mechanisms for each of the external actors. First, it analyses the main objectives of Russia and the EU in the post-Soviet countries under study; second, it looks at the degree of dependency of post-Soviet states on external actors (leverage), which can be instrumentalized by them for achieving their objectives; third, it explores instruments and methods used by Russia and the EU to achieve their goals; and 
finally it examines how their modes of engagement affect regime outcomes and the overall degree of democracy over time in the states under study.

In the third section, the influence of external actors on one particular aspect of democracy, which seems to have acquired special importance in the post-Soviet era - the electoral regime - is closely analyzed in a detailed case study.

Finally, the current chapter of conclusions summarizes empirical findings and proposes a refined theoretical argument on how, and to what extent, the external environment influences regime dynamics in the post-Soviet states under study.

\subsection{Hypothesis}

\subsubsection{Domestic conditions for democratization}

Although the main research interest of the current project lies at the external level of democratization, first of all, it is important to know which domestic conditions are necessary for successful communication between the external environment and the processes of democratization. In the end, democratization and autocratization are, above all, domestic processes in which external actors have, at most, an accelerating or hampering influence. Moreover, in the case of weak states with neighboring strong regional actors, the dividing lines between the domestic and external factors are quite blurred. In Belarus, for instance, one can argue that the "social contract" based on the provision of a relatively high quality of living standards is the main reason why Lukashenko has been so successful in building the most authoritarian state in this part of the world. Whereas the efficient economic performance might be a domestic product, its main drivers - gas and energy subsidies combined with the cheap loans and credits - are definitely of an external nature. Thus, conceptually, it is quite unclear whether the "economic miracle" of Belarus should be considered as a domestic or as an external phenomenon.

Nevertheless, the identity of political elites seems to be a very important and necessary condition for overcoming authoritarian stability and achieving higher quality of democracy or democratic regime outcome. In fact, the identity of elites seems to be a more relevant factor than other domestic factors, such as the culture of mass protest. The Armenian example explicitly shows that opposition unity, mass rallies, and social outrage are not sufficient conditions for achieving a democratic regime outcome if the incumbent regime does not share Western values and does not seek integration in the Western world. Politically, Armenia is one of the most pluralistic states in the region and has the strongest tradition of mass mobilization against the government's poor democratic record. Yet authoritarian rulers, backed 
both by Russia and by the EU, have, so far, managed to survive political turbulences at home. On the other hand, when external conditions are more conducive for democratic regime outcome and high quality of democracy, they can empower public discontent and mass mobilization in the struggle against authoritarian governments. The study has shown that mass mobilization against authoritarianism, combined with sufficient external support, strongly correlates with democratic regime outcomes and a higher degree of democracy. Thus, next to elite identity, prodemocratic mass mobilization is the second most important domestic condition for democratic change. Yet, as the empirical results have shown, external support is a key factor, which makes the necessary domestic conditions - either the presence of pro-European elites or existence of pro-democratic mass mobilization - sufficient for democratic regime outcome or for the increase of democratic quality. Compared to mass mobilization and elite identities, degree of (limited) statehood and security-related factors cannot explain directly the variance in quality of democracy and in regime outcomes. Contrary to many Europeanization studies, which see limited statehood as a hindering factor for democratization, empirical analysis show a negative correlation between the degree of limited statehood and the low degree of democracy and autocratic regime outcomes. Armenia and Belarus show a higher degree of stability and statehood, but enjoy a lower degree of democracy and have witnessed only autocratic regime outcomes. More democratic Georgia and Ukraine, on the other hand, have been less stable and had to cope with a variety of security- and statehood-related problems.

That is not to say, however, that the role of limited statehood is less important than that of the other domestic factors. Limited statehood and a destabilized security environment affect both the capabilities of the incumbent elites to implement political reforms and contribute to the establishment of a "security-first discourse," which makes the issue of the democratization agenda less relevant for the public and the political elite. Moreover, the presence of statehood- and security-related problems also affect the strategy of external actors, first of all that of the EU. The EU is often forced to redirect much of its capacity-building activities towards state- and institution building, focusing more on output-related and less on inputrelated outcomes. Nevertheless, as empirical analysis has shown, neither the limited statehood nor the destabilized security environment could force the EU to wholly replace its democratic conditionality approach with a strategy of authoritarian stability in situations when it decided to empower democratic processes, as was the case in Georgia and Ukraine. 


\subsubsection{External influences and regime dynamics}

\subsubsection{Impact of Russia}

Overall, empirical evidence from all four post-Soviet states under study suggests the negative correlation between the amount of Russian leverage and the degree of democracy (H4). Russian leverage has been the highest in Belarus and Armenia, and both states have experienced stable authoritarian systems over the past fifteen years. In Georgia, Russia's leverage steadily decreased starting in 2005. In just a few years of reduced Russian influence, the South Caucasus country considerably improved its democratic record. In Ukraine, the decrease in Russian leverage was accompanied by an increase in the quality of democracy after the Orange Revolution; the democratic trend was reversed, however, after 2010, whereas Russian leverage remained unchanged.

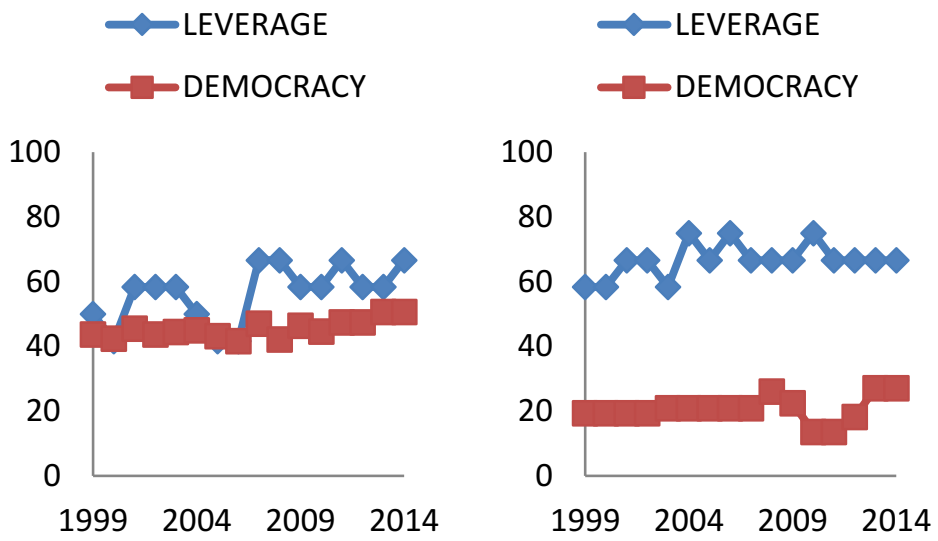

Figure 35: Democratic quality and Russian leverage in Armenia (L) and Belarus (R) 
$\sim$ LEVERAGE

$\longrightarrow$ DEMOCRACY

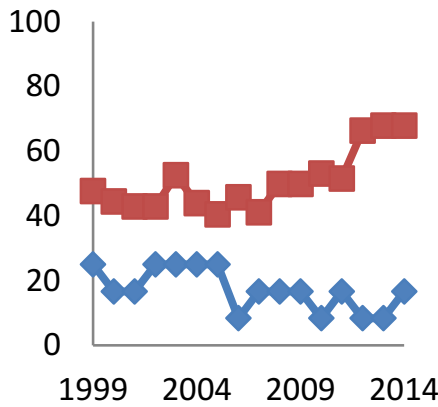

LEVERAGE

$-D E M O C R A C Y$

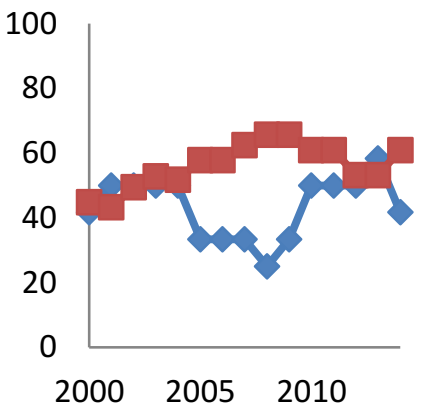

Figure 36: Democratic quality and Russian leverage in Georgia (L) and Ukraine (R)

\subsubsection{How does Russia affect regime dynamics in the post-Soviet states?}

The study's empirical analysis confirmed the research hypothesis regarding Russia's role as the main sponsor of authoritarianism in its neighborhood. Yet, in the most part, Russian support of authoritarianism has been indirect. In Russiafriendly post-Soviet states, Russia assists the post-Soviet authoritarian incumbents by providing material help to sustain their economic and social systems. Russian gas and oil subsidies, loans and access to its labor market are instrumental for the economic survival of the incumbent regimes in Armenia and Belarus. Thus, the hypothesis on Russia's negative impact on pro-Russian post-Soviet regimes (H4.1) has largely been confirmed.

At the same time, Russia does its best to block the approximation of pro-Russian authoritarian states to the West, thus insulating them from the Western world and its potential democratizing effect. Moreover, Russia's unconditional support of friendly incumbents decreases their vulnerability to the EU and the US, helping them to escape Western democratization pressure. Thus, Russia's strategy in friendly post-Soviet states also negatively affects the EU's democracy-promotion agenda towards those countries (H6.2). 
In the post-Soviet states that are not friendly to Russia, and which are generally more democratically-governed than the pro-Russian countries, Moscow resorts to the entire set of coercive methods spanning from economic and energy embargoes to military conflicts and full-scale wars. This hinders the democratization process in those countries in three ways: First, it weakens a very basic precondition for successful democratic development - statehood and state institutions. The authorities are forced to invest most of the state's resources to tackle security and economic problems, which shifts their focus away from pursuing an agenda of political reforms. Second, weakening the statehood negatively affects those states' chances to move closer to Western institutions. Neither the EU nor NATO is willing to integrate into their structures weakened states that experience acute security problems, cannot control their territories or have a complicated relationship with Russia. NATO's refusal to grant Georgia and Ukraine a Membership Action Plan (MAP) in 2008 is a case in point. Kremlin's attempt to derail the DCFTA ratification process between the EU and Ukraine is another example. Thus, the Kremlin has been holding a de facto veto over the integration processes of its neighboring countries into the Euro-Atlantic structures. Third, the Russian strategy to destabilize its neighbors politically and economically also affects Western engagement in the region. The EU and the US are often forced to focus on state-building activities, shifting their focus away from a democracy-supporting agenda. In short, the Russian presence in pro-Western post-Soviet states has largely undermined the democratic processes in these states, which mostly confirms the hypothesis on Russia's negative impact (H4.2).

Moreover, the second and third points also prove the hypothesis on Russia's impact on the EU's democracy-promotion strategies in the pro-Western states in the shared neighborhood. Russia has had a largely negative effect on the EU's democratizing impact in these states (H6.1).

In contrast to indirect assistance, Russia's direct support to authoritarianism is visible only in the area of the electoral regime. Russia provides authoritarian states with external legitimacy by legitimizing fraudulent elections and protecting the incumbent regimes from Western criticism.

Other forms of autocracy assistance, such as authoritarian norm diffusion, have not been the focus of the study. However, the literature on authoritarian diffusion, which is more developed than that of indirect influences, has so far failed to identify common patterns of norm diffusion in the post-Soviet states. The role of Russia in the diffusion process is even more doubtful. In fact, many authors argue that Russia is not necessarily a primary source of authoritarian norms diffusion and 
that often the common authoritarian practices have different sources of origin (Bader 2012a, 2012b). In this regard, Belarus and Kazakhstan are the "usual suspects" (cf. Wilson 2011). Moreover, the degree of authoritarianism in Russia has, for many years, been much lower than in many post-Soviet states. Freedom House designated Russia as "Consolidated Authoritarian Regime" first time in 2009 whereas other post-Soviet states, such as Belarus and Azerbaijan, have long been part of this group (Shkolnikov 2009).

But, even if one considers Russia as a source of diffusion of authoritarian norms in post-Soviet space, there is no evidence that the diffusion of norms has taken place against the political will of the post-Soviet states in a coordinated manner, or that they have been imposed by Russia. Russia surely serves as a point of reference for its neighbors. The simple existence of a regional hegemon with a stable authoritarian system that is willing to dominate the neighborhood might encourage its autocratic neighbors to emulate authoritarian norms. However, this is the important question to ask: is Russia to blame for the spread of authoritarian norms if they are taken by the post-Soviet states deliberately and without any coercive measures? From the viewpoint of this study, it is, at the least, not intentional support for authoritarianism. The only place where we can clearly observe Russia actively promoting authoritarianism by undermining the democratic processes is the electoral regime. Other than that, the empirical evidence of Russia's direct support for authoritarianism is scarce. Even the Freedom House, which has staunchly supported the view that Russia actively promotes authoritarianism through norm diffusion and direct assistance, rarely delivers clear empirical examples to support its claim. Instead, Russian support is best considered as a "tacit" (Walker 2011b, 1).

To conclude, most of Russia's autocracy promotion is indirect: it bolsters postSoviet authoritarian regimes by financial, political and military means to ensure that they are not vulnerable to Western pressure and the stability of their regimes is long-lasting. Other than that, the Kremlin does not seem to be interested in how authoritarianism evolves in its neighboring states, what shape it takes or which authoritarian norms it emulates. In this sense, one can even ironically argue that Russia has a more liberal normative approach to its neighboring region than the West, as it does not prescribe exactly what kind of authoritarian forms its neighboring states should adopt to remain part of the Russia-led alliance system. As long as Western influence does not increase and there is no danger of democratic contagion à la "Orange virus", the Kremlin appears not to care how its neighboring states conduct their domestic politics. Yet, Russian financial and political assistance is instrumental for the authoritarian regimes in its neighborhood to survive 
and flourish. Russia does not deliberately spread particular forms of authoritarianism, but authoritarianism cannot survive without Russia's help. To put it bluntly, Russia does not necessarily serve as a model of authoritarianism for post-Soviet autocrats, rather it gives them resources and protection in order to cultivate their own authoritarianism models.

\subsubsection{Impact of the $\mathrm{EU}$}

As in case of Russia, overall, empirical evidence supports the hypothesis on the influence of the EU (H5): an increase in EU's influence is accompanied by an increase in the democratic quality (Figure 38-39). In Belarus, the EU's leverage has been low for the past fifteen years, as has the quality of democracy. In Armenia, the EU and the US enjoyed more leverage but it could not use it to substantially affect the democratic quality of the regime. Moreover, many attempts by the Armenian opposition to organize an Armenian color revolution have been unsuccessful. In Georgia and Ukraine, EU and US leverage has remained high and has increased over the past several years. Overall, that trend has correlated with a higher degree of democracy and more democratic regime dynamics in the two countries. Yet, higher Western leverage did not always correlate with a higher degree of democracy. For instance, Georgia's level of democracy remained low until 2010, whereas Western leverage has been stable and at a high level since 2000 (Figure 39). Therefore, as in the case of Russia, to explain the causal impact of the $\mathrm{EU}$ on regime outcomes and democratic quality in post-Soviet states, we have to look at the EU's instruments and the strategies in the region. 
$\sim$ LEVERAGE

DEMOCRACY

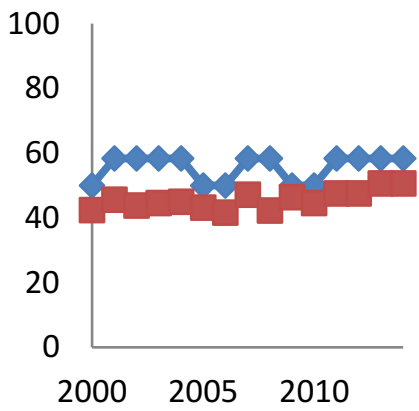

$\leadsto$ LEVERAGE

$-D E M O C R A C Y$

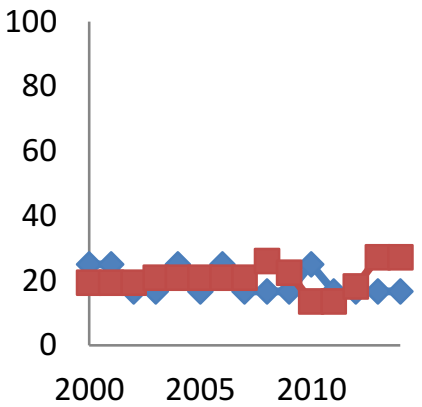

Figure 37: Democratic quality and leverage of the EUin Armenia and Belarus

$\sim$ LEVERAGE

DEMOCRACY

100

80

60

40

20

0 $\sim$ LEVERAGE

-DEMOCRACY

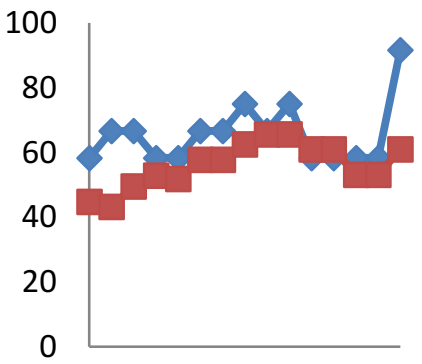

Figure 38: Democratic quality and leverage of the EU in Georgia and Ukraine 


\subsubsection{How does the EU affect regime outcomes and quality of democracy in the post-Soviet states?}

The EU is supposed to be the most important democracy-promoting actor in the post-Soviet region. Yet, the study delivers decidedly mixed results regarding the EU's democracy-promoting agenda. The empirical analysis identified two modes of EU political engagement that impact regime dynamics in the region in a variety of ways. Based on the Europeanization literature, the two modes have been conceptualized as a strategy of democratic conditionality and a strategy of supporting authoritarian stability. In addition, the EU has relied on political dialogue, which has not been an independent strategy on its own, but rather has included elements of both main modes: an active engagement with the government and the tacit use of political conditionality.

The First mode has been supporting authoritarian stability. Both the EU and the US have pursued the strategy of authoritarian stability - supporting authoritarian regimes and neglecting their democratic shortcomings - in a number of cases. This mode has been most evident in Armenia, over the full period of analysis, and in Georgia from 2004-2010. Unsurprisingly, the use of the strategy of authoritarian stability contributed to a lower degree of democracy and decreased chances of democratic regime outcomes as hypothesis 5.2 suggested.

The second mode was based on the consistent use of democratic conditionality as a means of democratic pressure on authoritarian incumbents. It was successfully employed during the Rose and Orange Revolutions in Georgia and Ukraine, and during the final years of Yanukovych's presidency in Ukraine. Yet, the case of Belarus, where Western political conditionality has profoundly failed, clearly shows that democratic conditionality only works when it is accompanied by the presence of the necessary domestic conditions: a pro-democratic population that is ready to mobilize en masse to stand for democratic values against the will of authoritarian regimes.

The third semi-mode is a mix of both main strategies. It relies on socialization strategies that employ political dialogue to persuade an incumbent to conduct democratic reforms. Political dialogue, however, is closely linked to democratic conditionality and only works when incumbent regimes show a clear ideational affinity with Western liberal democratic values. Thus, political dialogue cannot be considered as an autonomous strategy, but rather as the additional feature of two previous strategies - political conditionality and authoritarian stability. 


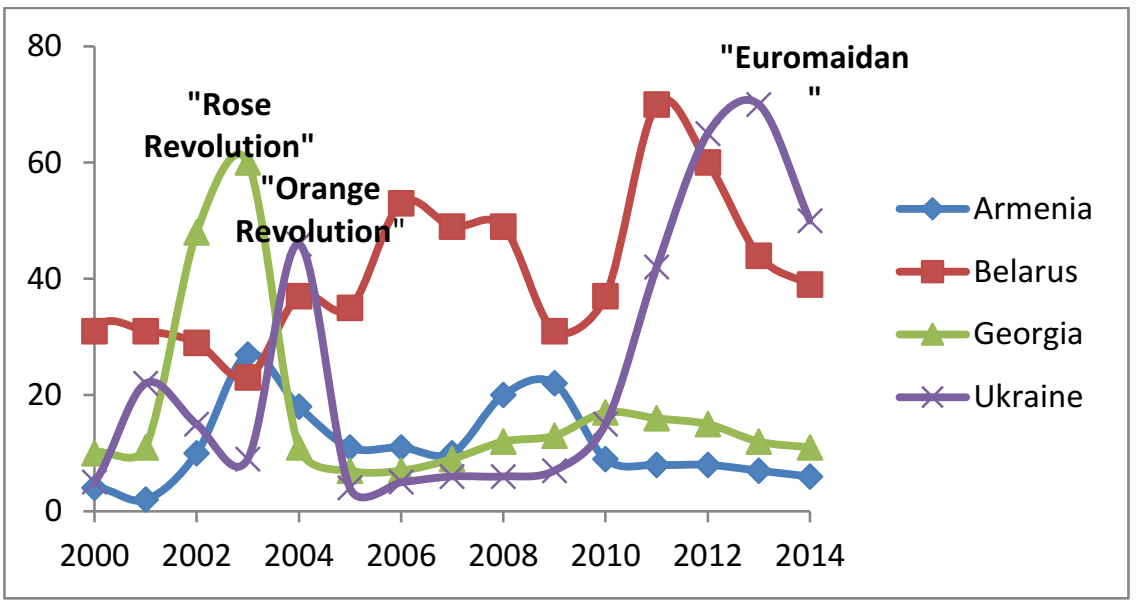

Figure 39: Evolution of the Western political conditionality over time (compiled by author)

Finally, the study also revealed a huge difference, in analytical terms, between Russia and the EU. It seems that Russia has a well-elaborated and clear-cut strategy on how to deal with its neighbors and it has been consistently following it over the past fifteen years. This strategy includes destabilizing the neighboring states that "don't follow the rules" to the extent that they are unwelcome in the West and are brought to the verge of a failed statehood. At that point the Kremlin either waits until a pro-Russian government takes power or it continues destabilization measures to prevent the emergence of strong, consolidated state that will not pursue a pro-Russian foreign policy. On the other hand, it supports pro-Russian incumbent regimes as long as there is no better alternative to replace them. At the same time, the Kremlin tries to acquire control stakes in the country's economy, energy, transport and communication sectors by using the economic and political weaknesses of those regimes. The common characteristic of Russia's strategies toward both pro-Russian and non-pro-Russian states is that Russia is hindering the emergence of strong and consolidated states on its borders. Even in pro-Russian states with Russia-friendly political elites, Moscow tries to control all important branches of the economy and the infrastructure. Moreover, it has not helped to resolve the security problems facing its friendly states, but rather has worked to 
maintain them in order to keep these countries vulnerable in terms of security and the military.

The EU, on the other hand, has been lost in the region for some time. It has a clearly defined vision what it wants to achieve, but has not yet been able to determine how to achieve it. Thus, there is no common pattern that can be identified in the EU's strategy over the past fifteen years. Rather, the EU's strategy has varied country-by-country and year-by-year. Armenia and Belarus are both pro-Russian states with authoritarian regimes, but the EU's approach toward them could not be more different. In Armenia, it has constantly backed the incumbent regime, whereas in Belarus the EU has deployed the strongest possible political conditionality. If the EU's strategy is, first of all, about promoting peace and stability, then their permanent pressure on Lukashenko does not fit into this picture, either.

Table 35: Russian and Western strategies in the post-Soviet states

\begin{tabular}{|c|c|c|}
\hline EU/West & $\begin{array}{l}\text { Shared Neighbor- } \\
\text { hood }\end{array}$ & Russia \\
\hline "Ring of Friends" & Vision of region & $\begin{array}{l}\text { "Sphere of Special In- } \\
\text { terests" }\end{array}$ \\
\hline $\begin{array}{l}\text { "Neighborhood" } \\
\text { "Partners" }\end{array}$ & $\begin{array}{l}\text { Geographic narra- } \\
\text { tive }\end{array}$ & $\begin{array}{l}\text { "Backyard" } \\
\text { "Common Civilization" }\end{array}$ \\
\hline $\begin{array}{l}\text { Stability, peace, democ- } \\
\text { racy and rule of law }\end{array}$ & Interests & $\begin{array}{l}\text { Political and economic } \\
\text { control }\end{array}$ \\
\hline $\begin{array}{l}\text { Instability, frozen con- } \\
\text { flicts, uncontrolled mi- } \\
\text { gration }\end{array}$ & Threats & $\begin{array}{l}\text { Spread of popular revo- } \\
\text { lutions; increased West- } \\
\text { ern presence }\end{array}$ \\
\hline $\begin{array}{l}\text { Sticks: } \\
\text { Withdrawal of financial } \\
\text { assistance; } \\
\text { Decrease in the level of } \\
\text { Integration; } \\
\text { Personal sanctions; } \\
\\
\text { Carrots: } \\
\text { Visa liberalization; } \\
\text { AA and DCFTA; } \\
\text { EIB/EBRD/IMF/WB } \\
\text { loans }\end{array}$ & Instruments & $\begin{array}{l}\text { Sticks: } \\
\text { Territorial conflicts; } \\
\text { Wars; } \\
\text { Trade embargoes; } \\
\text { Energy wars; gas price } \\
\text { hikes; } \\
\text { Imposition of visa re- } \\
\text { gimes; } \\
\text { Carrots: } \\
\text { Energy subsidies } \\
\text { Cheap loans }\end{array}$ \\
\hline
\end{tabular}




\begin{tabular}{|c|c|c|}
\hline Mostly governmental & $\begin{array}{l}\text { Channels of Influ- } \\
\text { ence }\end{array}$ & Mostly governmental \\
\hline $\begin{array}{l}\text { Democratic Condi- } \\
\text { tionality } \\
\text { Impact on democracy: } \\
\text { Positive }\end{array}$ & Main Strategies & $\begin{array}{l}\text { Boosting the } \\
\text { friendly regimes } \\
\text { Impact on democracy: } \\
\text { Negative }\end{array}$ \\
\hline $\begin{array}{l}\text { Authoritarian Stabil- } \\
\text { ity } \\
\text { Impact on democracy: } \\
\text { Negative }\end{array}$ & & $\begin{array}{l}\text { Destabilizing the } \\
\text { "disobedient" re- } \\
\text { gimes } \\
\text { Impact on democracy: } \\
\text { Negative }\end{array}$ \\
\hline
\end{tabular}

\subsubsection{Regime outcomes and democratic quality}

Finally, the strategies used by external actors also account for the discrepancy between democratic regime outcomes and a higher quality of democracy in postSoviet space, which has been one of the main puzzles of this study. Based on the in-depth research conducted for this thesis, I identified three reasons why democratic regime outcomes are not always followed by high quality of democracy: the Russian strategy of supporting democratically elected incumbents; the EU's inconsistent application of democratic conditionality; and the EU's exclusive focus on elections. First, the Kremlin assists pro-Russian leaders, after they come to power through democratic elections, to maintain power through undemocratic means. A case in point was Russia's strong support for democratically elected Yanukovych, who later roll backed his predecessors' democratic reforms and tried to build an autocratic system. Russia's negative role, however, is neither surprising nor decisive. The EU has been more influential, and through its inconsistent application of democratic conditionality and often exclusive focus on elections, has failed to lock in the democratic momentum achieved through democratic regime outcomes. For instance, the EU's decision to abandon democratic conditionality soon after the Rose Revolution was one of the main reasons why the democratic regime outcome in Georgia was followed by a decrease in democratic quality. In addition, the results of this thesis largely confirm conventional wisdom about electoral fallacy: elections in post-Soviet states have often occupied most of the EU's attention. Hence, problems in other areas of democracy have often been overlooked. 
Table 36: Cases of negative correlation between regime outcomes and democratic quality

\begin{tabular}{|l|l|l|l|}
\hline Election & $\begin{array}{l}\text { Regime Out- } \\
\text { come }\end{array}$ & External impact & $\begin{array}{l}\text { Quality of De- } \\
\text { mocracy }\end{array}$ \\
\hline Georgia & $\begin{array}{l}2003 \text { Rose } \\
\text { Revolution }\end{array}$ & $\begin{array}{l}\text { EU/US uncondi- } \\
\text { tional support to Saa- } \\
\text { kashvili }\end{array}$ & $\begin{array}{l}\text { 2004-2010 } \\
\text { Stagnation, de- } \\
\text { crease }\end{array}$ \\
\hline Ukraine & $\begin{array}{l}2010 \text { demo- } \\
\text { cratic elections }\end{array}$ & $\begin{array}{l}\text { Russia's uncondi- } \\
\text { tional support to } \\
\text { Yanukovych }\end{array}$ & $\begin{array}{l}\text { 2010-2014 } \\
\text { Stagnation, de- } \\
\text { crease }\end{array}$ \\
\hline
\end{tabular}

\subsection{External environment as a passive factor}

Although the main research interest of this thesis was limited to the regional actors - Russia and the EU, which try to actively promote their views and interests in the shared neighborhood-the passive dimension of regional context proved to be important as well. The regional environment affects regime outcomes and the degree of democracy as a passive external factor. One example of this is how authoritarian regimes instrumentalize the external environment to consolidate state power in their hands. As exemplified in the previous chapters, Russia and the EU try to influence domestic processes in the post-Soviet states through various means. At the same time, both external actors, through their complicated interaction in the post-Soviet area, produce a high degree of tensions in the region, which is then skillfully used by the local autocrats to boost their power base. Three out of the four post-Soviet state under study - Armenia, Georgia and Ukraine- are surrounded by an environment with a deteriorated security situation, which has had a direct impact on democratic processes in those states. In all four post-Soviet states, each election was portrayed by the local political elites not only as a domestic process of power rotation, but as a decisive struggle between pro-Western and proRussian forces or between patriots and foreign agents. The incumbent regimes, on their part, have further instrumentalized the fragile security situation to overshadow the need for democratic development. Every possible power change has been portrayed by the ruling regimes as a dangerous possibility that could change the foreign policy orientation of the country. For instance, after the 2008 election crisis in Armenia, Hrant Markarian, a senior leader from the pro-government ARF party, denounced the opposition protests as a part of "a foreign plot" seeking to 
stage "a pro-Western revolution" in Armenia", and added that "unspecified external forces seek to weaken the country", offering "fertile ground for external interference" (RFE/RL Newsline 2008b). The Belarusian regime, on its part, has often justified the repressions and further consolidation of power by the threat of hostile Western nations, which "conspire against sovereign Belarus" (Melyantsou 2012, 3). The Georgian government under Mikhail Saakashvili used the same methods to consolidate its grip on power. The adoption of controversial constitutional changes in 2006, which extended the term of the parliament by several months and further empowered the position of president, was justified by the necessity of "consolidating power in the face of pressure from Russia"(RFE/RL 20061). Moreover, post-Soviet authoritarian regimes have often portrayed the deteriorated security situation as the main reason for their poor democratic record in the periods between elections. On the other hand, when there is a weak statehood and a fragile security situation was so omnipresent, the state stability has become an overrated commodity. The Armenian leadership has often underlined the "stability" and "an established state" as an instrumental part of achieving the economic growth (RFE/RL 2005c).

One can certainly argue that the tricky strategies used by authoritarian governments do not have much to do with the external environment but rather are a mere product of the pragmatic survival strategies of an authoritarian regime and an underdeveloped political culture. The fact is, however, that since the mid-1990s the international environment has became increasingly polarized for most of the postSoviet states. Whereas the instrumentalization of external threats for the solution of domestic problems is, as such, a clear sign of the lack of political culture, deteriorated external conditions have also contributed to this trend. The international environment has provided the post-Soviet authoritarians with fertile ground for an easy justification of their authoritarian practices.

The polarized international environment also made it difficult to resolve territorial conflicts and other security-related issues. When Armenian President Levon TerPetrosyan tried to negotiate a peace plan with Azerbaijan, he was obstructed by his own ministers and forced to resign. Similarly, after ten years, when the newly elected President Serzh Sargsyan started the so-called "football diplomacy" with Turkey to normalize relations and open borders, he came under heavy criticism from both allies and the opposition. In 2009, Armenian Revolutionary Federation (ARF, Dashnaktsutsyun), one of the two minor partners in a governing coalition since 2007 , left the coalition in protest to the process of normalization of relations with Turkey, which they believed could jeopardize the worldwide campaign for the recognition of Armenian Genocide. (RFE/RL 2009a). The ARF was joined by 
the majority of the Armenian opposition, who argued that the normalization of relations with Turkey and the acceptance of the resolution of Karabakh conflict based on the so- called Madrid Principles, which were elaborated by the Minsk Group in 2007, would mean abandoning both the international recognition of the genocide and of the Republic of Karabakh (Bulghadarian and Danielyan 2009). In addition, security-related issues have, at times, also influenced the strategies of opposition forces in the EaP states, forcing them to make political concessions for the sake of their countries' overall security. For instance, following the 2008 Russia-Georgia war, the Georgian opposition refrained from pressuring the authoritarian government under Saakashvili for a few years, in order not to weaken the government's position in the international arena. Similarly, the Armenian opposition has often considered itself to be obliged to refrain from applying pressure on the Armenian authorities in order not to weaken its position amidst external pressure over the Nagorno-Karabakh conflict (Stepanian 2010a).Thus, Russia and the $\mathrm{EU}$, together with other external or regional actors, are not just actively contributing to the lower quality of democracy in the post-Soviet states. Through their rivalry, they also build a conflict environment, which indirectly contributes to the strengthening of authoritarian structures and the low level of democratic quality in their shared neighborhood.

\subsection{Regional pattern: What kind of world?}

The study also tried to explain the broader issue of why we have such a heterogeneous picture of democratic development in the post-Socialist world. Even though the elaboration of interregional differences was not the primary task of the study, based on our conclusions, we can still touch this issue.

Based on the empirical analysis in the study, it can be assumed that the common neighborhood of the EU and Russia is not necessarily post-Socialist by nature but rather represents a post-post-Socialist world. The post-socialist world, as we knew it, ended in the late nineties of the last century, at least in terms of democracy and democratization. The Third Wave of post-socialist democratization was mostly confined to the CEE and, to some extent, to the states of Western Balkan. However, the post-Soviet states were never part of the successful story of democratization. Crucial domestic and external differences separated them from the other parts of the post-socialist world both spatially and temporally. This separation was finalized at the end of 1990s, when Russia finally consolidated its power and started to reassert its influence in the near abroad. Thus, in terms of 
democratic transition and democratization, the post-Soviet states of the former Soviet Union and the post-Socialist states in the CEE and Western Balkans have very little in common.

The new regional environment, which has risen since the late 1990s, crucially differs both from the Cold War - style confrontation period and from the post-Cold War unipolar system. It was the unipolar, Western-centered regional context that fostered the democratization of the CEE. In post-Soviet space, we have a situation where different external actors compete with each other through their integration visions. The persistence of hybrid regimes as the most common regime type across post-Soviet space is the very logical manifestation of this multidimensional international context. The nature of the post-post-Socialist world leaves the post-Soviet states without the external push for democratization, which makes democratic consolidation more difficult for them, compared to the CEE and the Western Balkans. Yet, the situation has changed slightly over the past few years. The launch of the Eastern Partnership and the ratification of the DCFTA and AA with Georgia, Moldova and Ukraine is the first attempt to integrate any of post-Soviet states into the European economic and political system. Although this was not meant to alienate Russia, the Kremlin found itself geopolitically challenged and resorted to countermeasures. The rivalry between the EU, which is supported by the US, and Russia in the post-Soviet area is partly due to radically different foreign policy discourses. The EU's post-modern, multilateral approach to regionalism and Russia's $19^{\text {th }}$ century mentality of a zero-sum game do not coexist easily. Yet, despite the side effects of this competition, the EU's increasing influence in the region has also been accompanied by the advance of pluralism and democracy in the some parts of the post-Soviet area. To make it clear, none of the post-Soviet states have managed to regain substantial independence from Russia. Yet, in the states where Russian and EU influence overlap (Georgia, Ukraine), the degree of democracy has slowly increased. In contrast, the states that have remained under Russia's heavy influence show a lower quality of democracy and have either experience authoritarian stability or even an authoritarian backlash (Armenia, Belarus). Figure 41 summarizes these trends. 


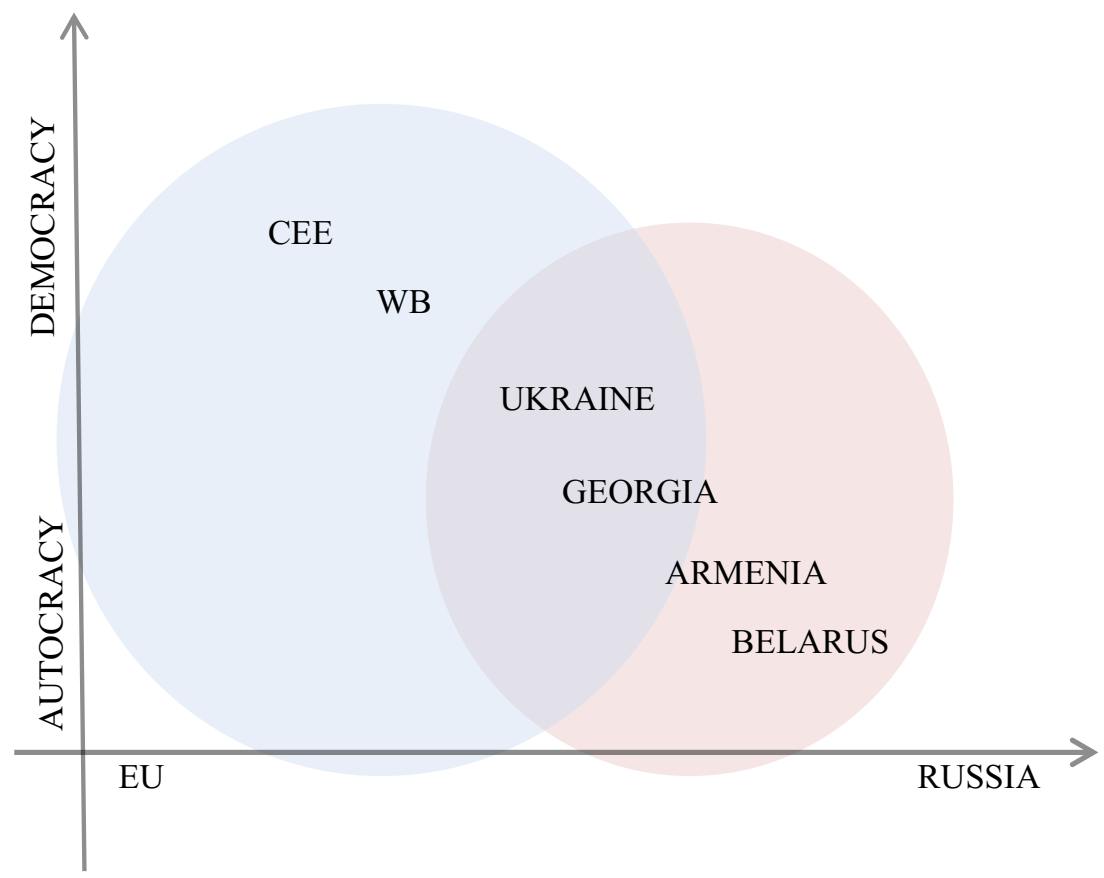

Figure 40: Influences of external actors and degree of democratization in the post-Soviet world

\subsection{Building a theoretical model}

To conclude, one of the main conclusions that emerged from the study is that a favorable domestic environment is necessary for a higher quality of democracy and democratic regime outcomes. The readiness of civil society and the public to mobilize and protest, or the presence of a government with a clear pro-European orientation, is a necessary ingredient for successful democratic change. If neither of these conditions are met, democratic regime outcomes and high quality of democracy will be unlikely, regardless of how democracy-friendly the external environment is. 
However, unfavorable external conditions can show their strength by blocking democratic change, even when the most favorable domestic conditions are present (as in the case of Armenia). Accordingly, although external factors cannot alone trigger an increase in the quality of democracy or democratic regime outcome, they can work as a democracy-blocker and push a favorable domestic context in the opposite direction, toward authoritarianism. We can conclude that the international environment on its own is not sufficient for democratic change to happen but it is sufficient to block it.

Finally, based on the empirical observations of the study, one general rule can be observed on how the international environment affects the regime outcomes and quality of democracy in the post-Soviet states: When the EU follows the democratic conditionality (Ukraine 2004, 2013, Georgia 2003, 2012) and Russian influence is softened (Georgia 2012), the country moves toward more democracy and the quality of democracy and the chances for democratic regime outcomes increase. When either the EU softens its conditionality approach (Armenia, Georgia 2008) or Russia succeeds in boosting the incumbent regime (Belarus), then the country is either stalled in a "grey zone" or moves toward authoritarianism and the quality of democracy decreases or remains at the same level. 
Table 37: External and domestic conditions for democratization in the post-Soviet states

\begin{tabular}{|c|c|c|c|c|c|}
\hline & $\begin{array}{l}\text { Pro- } \\
\text { Western } \\
\text { elites }\end{array}$ & $\begin{array}{l}\text { Public } \\
\text { protests }\end{array}$ & Russia & West & Outcome \\
\hline $\begin{array}{l}\text { ARM } \\
2000\end{array}$ & - & - & $\begin{array}{l}\text { Regime boost- } \\
\text { ing }\end{array}$ & $\begin{array}{l}\text { Authoritarian } \\
\text { Stabilization }\end{array}$ & Autocratic \\
\hline $\begin{array}{l}\text { ARM } \\
2003\end{array}$ & - & Present & $\begin{array}{l}\text { Regime boost- } \\
\text { ing }\end{array}$ & $\begin{array}{l}\text { Authoritarian } \\
\text { Stabilization }\end{array}$ & Autocratic \\
\hline $\begin{array}{l}\text { ARM } \\
2004\end{array}$ & - & Present & $\begin{array}{l}\text { Regime boost- } \\
\text { ing }\end{array}$ & $\begin{array}{l}\text { Authoritarian } \\
\text { Stabilization }\end{array}$ & Autocratic \\
\hline $\begin{array}{l}\text { ARM } \\
2007\end{array}$ & - & - & $\begin{array}{l}\text { Regime boost- } \\
\text { ing }\end{array}$ & $\begin{array}{l}\text { Authoritarian } \\
\text { Stabilization }\end{array}$ & Autocratic \\
\hline $\begin{array}{l}\text { ARM } \\
2008\end{array}$ & - & Present & $\begin{array}{l}\text { Regime boost- } \\
\text { ing }\end{array}$ & $\begin{array}{l}\text { Authoritarian } \\
\text { Stabilization }\end{array}$ & Autocratic \\
\hline $\begin{array}{l}\text { ARM } \\
2012\end{array}$ & - & - & $\begin{array}{l}\text { Regime boost- } \\
\text { ing }\end{array}$ & $\begin{array}{l}\text { Authoritarian } \\
\text { Stabilization }\end{array}$ & Autocratic \\
\hline $\begin{array}{l}\text { ARM } \\
2013\end{array}$ & - & Present & $\begin{array}{l}\text { Regime boost- } \\
\text { ing }\end{array}$ & $\begin{array}{l}\text { Authoritarian } \\
\text { Stabilization }\end{array}$ & Autocratic \\
\hline $\begin{array}{l}\text { BEL } \\
2001\end{array}$ & - & - & $\begin{array}{l}\text { Regime boost- } \\
\text { ing }\end{array}$ & Conditionality & Autocratic \\
\hline $\begin{array}{l}\text { BEL } \\
2004\end{array}$ & - & - & $\begin{array}{l}\text { Regime boost- } \\
\text { ing }\end{array}$ & Conditionality & Autocratic \\
\hline $\begin{array}{l}\text { BEL } \\
2006\end{array}$ & - & - & $\begin{array}{l}\text { Regime boost- } \\
\text { ing }\end{array}$ & Conditionality & Autocratic \\
\hline $\begin{array}{l}\text { BEL } \\
2008\end{array}$ & - & - & $\begin{array}{l}\text { Regime boost- } \\
\text { ing }\end{array}$ & Conditionality & Autocratic \\
\hline $\begin{array}{l}\text { BEL } \\
2010\end{array}$ & - & - & $\begin{array}{l}\text { Regime boost- } \\
\text { ing }\end{array}$ & Conditionality & Autocratic \\
\hline $\begin{array}{l}\text { BEL } \\
2011\end{array}$ & - & - & $\begin{array}{l}\text { Regime boost- } \\
\text { ing }\end{array}$ & Conditionality & Autocratic \\
\hline $\begin{array}{l}\text { BEL } \\
2012\end{array}$ & - & - & $\begin{array}{l}\text { Regime boost- } \\
\text { ing }\end{array}$ & Conditionality & Autocratic \\
\hline $\begin{array}{l}\text { GEO } \\
2000\end{array}$ & - & - & $\begin{array}{l}\text { Regime desta- } \\
\text { bilization }\end{array}$ & $\begin{array}{l}\text { Authoritarian } \\
\text { Stabilization }\end{array}$ & Autocratic \\
\hline $\begin{array}{l}\text { GEO } \\
2003\end{array}$ & - & Present & $\begin{array}{l}\text { Regime desta- } \\
\text { bilization }\end{array}$ & Conditionality & Democratic \\
\hline $\begin{array}{l}\text { GEO } \\
2004\end{array}$ & Present & - & $\begin{array}{l}\text { Regime desta- } \\
\text { bilization }\end{array}$ & $\begin{array}{l}\text { Authoritarian } \\
\text { Stabilization }\end{array}$ & Autocratic \\
\hline
\end{tabular}




\begin{tabular}{|l|l|l|l|l|l|}
\hline GEO & Present & Present & $\begin{array}{l}\text { Regime desta- } \\
\text { bilization }\end{array}$ & $\begin{array}{l}\text { Authoritarian } \\
\text { Stabilization }\end{array}$ & Autocratic \\
\hline $\begin{array}{l}\text { GEO } \\
2008\end{array}$ & Present & Present & $\begin{array}{l}\text { Regime desta- } \\
\text { bilization }\end{array}$ & Reinforcement & Autocratic \\
\hline GEO & Present & Present & $\begin{array}{l}\text { Regime desta- } \\
\text { bilization }\end{array}$ & Conditionality & Democratic \\
2012 & & & $\begin{array}{l}\text { Regime desta- } \\
\text { bilization }\end{array}$ & Conditionality & Democratic \\
\hline GEO & Present & - & $\begin{array}{l}\text { Regime boost- } \\
\text { ing }\end{array}$ & $\begin{array}{l}\text { Authoritarian } \\
\text { Stabilization }\end{array}$ & Autocratic \\
\hline UKR & - & - & $\begin{array}{l}\text { Regime boost- } \\
\text { ing }\end{array}$ & Conditionality & Democratic \\
\hline UKR & - & Present & $\begin{array}{l}\text { Regime boost- } \\
\text { ing }\end{array}$ & Conditionality & Autocratic \\
\hline UKR & - & - & $\begin{array}{l}\text { Regime boost- } \\
\text { ing }\end{array}$ & Conditionality & Democratic \\
2010 & & Present & & &
\end{tabular}

Table 37 summarizes empirical results on external and domestic conditions for democratic regime outcomes in the four post-Soviet states over time. In all cases, when the violation of democratic norms by authoritarian rulers have been either reversed or prevented, either of two domestic conditions - pro-democratic mass mobilization or pro-European ruling elite - has been present.

Yet, they have always been accompanied by the democratic conditionality applied by the EU. Moreover, whereas Russia has overall played a negative role by opposing democratic openings and supporting authoritarian regimes, especially in Ukraine, the combination of a strong domestic pull (mass mobilization or proEuropean elites) and the Western push (democratic conditionality) has, in most cases, outweighed Russian counterinfluence. Thus, regardless of the role of Russia, the presence of both democratic conditionality and a strong domestic pull has always resulted in a successful democratic opening. Yet, the role of Russia should not be underestimated, as it has often successfully bolstered authoritarian regimes against the threats of democratization, especially when either the domestic conditions have not been strong enough (Belarus), or when the democratizing pressure of the EU has been absent (Armenia).

Based on the empirical results, we can make a three-step argument about when the democratization in post-Soviet area is possible and when it is not.

- When the EU political conditionality is strong and the domestic conditions are present, the result is a democratic regime outcome and higher quality of democracy regardless of the other variables. 
- When the domestic conditions are not strong enough, even if the EU conditionality is present, the result is a lower quality of democracy and the continuation of authoritarian rule.

- When the domestic conditions are present but the EU conditionality is absent, the result is a lower quality of democracy and the continuation of authoritarian rule.

- The role of Russia is decisive in the second and third options when either the EU pressure is absent or the domestic conditions are weak.

Table 38: Summary of main argument

\begin{tabular}{l|l|l} 
Russia & $\begin{array}{l}\text { Democratic Condition- } \\
\text { ality }\end{array}$ & $\begin{array}{l}\text { Authoritarian Stabili- } \\
\text { zation }\end{array}$ \\
\hline Regime boosting & $\begin{array}{l}\text { Democracy if either } \\
\text { pro-EU elites or mass } \\
\text { mobilization present } \\
\text { Autocracy if neither are } \\
\text { present }\end{array}$ & $\begin{array}{l}\text { Autocracy regardless } \\
\text { of presence of pro-EU } \\
\text { elites or mass mobili- } \\
\text { zation }\end{array}$ \\
\hline Regime destabilization & $\begin{array}{l}\text { Democracy if either } \\
\text { pro-EU elites or mass } \\
\text { mobilization present } \\
\text { Autocracy if neither are } \\
\text { present }\end{array}$ & $\begin{array}{l}\text { Autocracy regardless } \\
\text { of presence of pro-EU } \\
\text { elites or mass mobili- } \\
\text { zation }\end{array}$ \\
\hline
\end{tabular}

\subsection{Academic and practical implications}

\subsubsection{EU: Bringing the conditionality back in}

Academic literature has criticized the EU's transformative impact on the democratization processes beyond its borders as inefficient. The lack of "the golden carrot" - the membership perspective - has been blamed for the EU's failure to transform its neighboring regions (Lehne 2014; Haukkala 2010; Schimmelfennig and Scholtz 2008; Whitman and Wolff 2010). Moreover, the overall commitment of the EU to its neighborhood seems to have weakened and it lacks both the material resources and political will. The situation has been further complicated by presence of a regional hegemon - Russia - which pursues its own agenda in the region 
and sees the EU as its main rival. The failure of the EU democracy promotion strategy beyond its borders has contributed to the emergence of new strands in the literature on democracy promotion and Europeanization. For instance, literature on democratic governance argues that since the EU has not been able to influence democratization in its neighborhood using traditional tools, it has to stick to a "democratization lite" version by focusing on the transfer of democratic norms at the policy levels.

Yet, contrary to conventional wisdom, the results of this study clearly show that democratic conditionality still works once certain domestic conditions are met. The comparative analysis has confirmed that the consistent use of democratic conditionality by the EU and the US provides democratic and pro-reform domestic agents with additional external leverage and limits the options of incumbent regimes, regardless of whether the membership incentive is in place or not. Thus, the main reason for the inefficiency of the neighborhood conditionality is not the absence of membership perspective; rather it is its inconsistent application by the Union.

Accordingly, the EU is well advised to apply the political conditionality in a consistent manner in its neighborhood, especially when domestic mobilization is in place.

Moreover, the EU should develop post-association mechanisms for the associated countries, which will ensure the continuation of political conditionality once all the juicy carrots (such as Association Agreement itself or liberalization of visa regimes) have already been eaten. The post-association mechanisms can be modeled on post-accession instruments, such as the Cooperation and Verification Mechanism in Bulgaria and Romania. The EU has to send a clear signal that the institutional approximation of the post-Soviet states to the Union is not irreversible and that any progress achieved in relations can be rolled back at any time.

\subsubsection{Russia: Non-ideological autocracy promotion}

Russia has been portrayed by the academic literature as a regional hegemon with assertive foreign policy goals. Yet the role of Russia in the democratic processes of its near abroad confuses many authors. This confusion is caused by the fact that Russia is often seen as a non-ideological pragmatic power that does not seek to promote any particular type of regime abroad (Bugajski 2011; Way 2015). Instead, it has been focused on pragmatic goals, such as regaining regional influence in post-Soviet states and establishing itself as an independent center of power in the 
world. Accordingly, Russia's negative impact on democratic developments in its near abroad has often been downplayed or relativized.

As this thesis has shown, however, Russia does not necessarily need a well-elaborated normative agenda to undermine the quality of democracy in its neighborhood. To study Russia's impact on the democratization processes in its neighborhood, we need to stop looking at Russia through a normative lens. As the empirical results of this thesis have shown, Russia as a pragmatic actor can also undermine democracy. This thesis identified at least four indirect methods through which Russia has been negatively influencing the democratic regime outcomes and quality of democracy in the states under study: supporting friendly authoritarian regimes against the Western pressure; destabilizing non-friendly states; blocking the approximation of both friendly and non-friendly states toward the EU and the NATO; and negatively affecting the democracy promotion strategies of the EU. Moreover, although Russia does not consider democracy as a threat, it has always linked democratic regime outcomes in its near abroad to the expanding influence of the West, primarily of the USA. Many in Kremlin believe that both the 2004 Orange Revolution and the 2013 protests in Ukraine were not a product of social outrage against the corrupt and autocratic regime, but rather foreign-made plots assisted by the EU and the US against the legitimate governments of Ukraine and, ultimately, against Russian interests. On the other hand, the successful mass mobilization in one of the post-Soviet states implies the danger of the contagion effect. The color revolutions in Georgia and Ukraine were followed by mass protests in Armenia and Belarus. The spillover of the Orange Revolutions into other postSoviet countries would endanger both Russia's dominant standing in the region and the stability of the regime itself. Thus, although Russia has not been a normative power, it has still had to engage in normative battle against democratic mobilizations and democratic regimes because it is part of the Kremlin regime's pragmatist survival strategy. There has never been a democratically governed state in the post-Soviet space that enjoyed good relations with Russia.

In summary, one can argue that Russia not being a normative actor does not make its impact on democracy in its neighboring countries less relevant. Its pragmatic goals and pragmatic foreign policy instruments undermine the quality of democracy and democratic regime dynamics in its neighborhood in many ways and to a considerable extent. 


\subsection{Outlook and further avenues for research}

The EaP, together with the Union for the Mediterranean (UfM), has been the EU's main foreign policy experience beyond the enlargement context. Some of the EaP countries have already signed Association Agreements (AA) with the EU including the DCFTAs. To fully evaluate the efficiency of the EU's transformative power in the areas of its neighborhood, we also need further research of the postAssociation era. The AA and visa liberalization became two major carrots at the EU's disposal once the membership perspective was off the table. AAs have already been signed with all three pro-EU post-Soviet countries - Georgia, Moldova and Ukraine - and the ratification of visa-free regimes with the three countries will probably be accomplished within the next two years. Further research may be conducted how the EU conditionality will evolve after both carrots have been fully consumed by the EaP countries.

This thesis analyzed the role of two main regional actors -Russia and the EU- on the regime outcomes and democratization processes in the post-Soviet states. I also included the role of the US and the NATO in the analysis, because they are inextricably linked to the EU when we deal with issues of democratization and democracy promotion. Yet, the international environment is becoming more and more complicated and more actors are starting to exert their influence in the region. First of all, the increasing economic and political influence of China should be studied. There have been some pioneer studies about China's growing influence in the post-Soviet states (Cecire 2015), yet the subject is still widely understudied, specifically in terms of China's impact on democratization. Moreover, the role of middle-sized regional actors, such as Turkey and Iran, in the processes of democratization has also been neglected by academic literature. Their influence has only been studied through the prism of security and energy politics.

In terms of the dependent variable, this thesis has focused on the impact of external actors on one particular area of democracy - electoral processes in the post-Soviet states. The scope of analysis can be expanded and include other partial regimes of democracy, as well. Further analysis can be conducted how Russia and the EU shape the evolution of other areas of democratic system, such as civil and political rights or horizontal accountability/checks and balances. So far, surprisingly few studies have addressed these issues.

We can also draw a few implications for other regions in the world since the struggle between democratic and authoritarian developmental models and their powerful backers is a global phenomenon, and is not limited to the post-Soviet world. 
Since the focus of the thesis is the strategy of the EU as the impediment or facilitator of democratic development, it would be reasonable to extend the research area by comparing the strategies of the EU in two neighboring regions in the east and the south. This can be an added value to the literature since there have been only a handful of studies incorporating both regions in their research. Most of the authors have focused only either on the Eastern or the Southern neighborhood of the EU. In this regard, this thesis provides several new avenues for further research. This thesis has also identified a number of factors, first of all - the role of statehood - which might explain the difference in EU approaches to the Southern and Eastern neighboring regions. Overall, the EU is liable to focus on security and stability more in the south than in the east, which might be due to the fact that the EU expects more security threats, such as the current migrant crisis or terrorism, coming more from the south than from the east. Another difference might lie in the presence of pro-European identities among the political elites and the broader public, which has been present in the east, but not in the south. All of this points to the significance of the domestic context in the EU's strategies. Further research could explore how the different domestic contexts in the Eastern and Southern neighborhoods shape the EU's strategies in the different ways.

The research can also be extended by comparing the EU's strategies in two postSoviet regions with different geographic proximities to the EU: the Eastern Partnership countries and the Central Asian states. The EU is perceived to be an even more reluctant democratizer in the Central Asia, focusing instead exclusively on dialogue over energy and security issues. In addition to the difference in geographic proximity, the less favorable domestic context and the absence of close institutional relationship also contribute to the EU's lack of focus on democratization in Central Asia. The region is also interesting because it falls in China's sphere of interest. Hence, in contrast to the $\mathrm{EaP}$ region, the $\mathrm{EU}$ has to compete with both Russia and China in Central Asia.

In general, the results of the study are mostly applicable to regions that neighbor the EU, where the EU enjoys an asymmetric relationship with third countries and can compete with other regional actors through the projection of soft power. By contrast, in more distant regions the EU's transformative power is limited due to the absence of institutional relations and the lack of attractive incentives. 